\title{
Development of Functional Ice Cream and Evaluation of Its Physico-Chemical, Microbiological and Sensory Characteristics
}

\author{
Geisa Demele Valério (I), Evelyn Marssola Castro (I), Luciana de \\ Jesus Bernini (I), Thiago Borges Pinto (I), Elsa Helena Walter de \\ Santana (I), Lina Casale Aragón-Alegro (I), Cínthia Hoch Batista de \\ Souza (I) \\ (I) UNOPAR - Universidade Norte do Paraná (Mestrado em Ciência e Tecnologia de Leite e \\ Derivados. R. Marselha,591, Londrina)
}

\section{Resumo}

Ice cream, food of high nutritional value and widely consumed, is presented as a promising alternative for the development of a functional food. To become a functional product, it can be enriched with the addition of probiotic microorganisms and prebiotic as inulin. The aim of this study was to evaluate the viability of probiotic Lactobacillus acidophilus La-5 added to ice cream, the effect of inulin on it, and the effect of its addition on the sensory and physico-chemical characteristics of products. Four ice cream formulations were produced in triplicate: T1 (control - without La-5 and inulin), T2 (probiotic - with addition of La-5) and T3 (prebiotic - with addition of inulin) and T4 (symbiotic - with addition of La-5 and inulin). Analyses of probiotic viability, physico-chemical ( $\mathrm{pH}$ and acidity) and sensory evaluation (9-point hedonic scale) were carried out weekly for 28 days during ice cream storage $\left(-18^{\circ} \mathrm{C}\right)$. La-5 counts were above 7 log $\mathrm{CFU} / \mathrm{g}$ for all formulations during the whole storage period. After 7 days of storage, were observed population of 7.43 (T2) and $7.60 \mathrm{log}$ CFU/g (T4). On day 28, populations observed were 7.45 (T2) and $7.47 \log$ CFU/g (T4). No significant reductions at the end of storage were observed: La-5 presented populations of 7.48 (T2) and $7.52 \mathrm{log}$ CFU/g (T4). The addition of inulin and La-5 did not significantly alter the $\mathrm{pH}$ and acidity of $\mathrm{T} 2$ and

\footnotetext{
Referência:

Geisa Demele Valério, Evelyn Marssola Castro, Luciana de Jesus Bernini, Thiago Borges Pinto, Elsa Helena Walter de Santana, Lina Casale Aragón-Alegro, Cínthia Hoch Batista de Souza.Development of Functional Ice Cream and Evaluation of Its Physico-Chemical, Microbiological and Sensory Characteristics. In: Anais do 120 Congresso Latinoamericano de Microbiologia e Higiene de Alimentos - MICROAL 2014 [= Blucher Food Science Proceedings, num.1, vol.1]. São Paulo: Editora Blucher, 2014. DOI 10.5151/foodsci-microal-022
} 
$\mathrm{T} 4$, since the results were similar to those found for $\mathrm{T} 1$. The average $\mathrm{pH}$ values between day 7 and 28 were 6.84 (T1), 6.76 (T2), 6.84 (T3) and 6.68 (T4). In the same period, T1, T2 and T4 showed average values of $0.16 \%$ acidity, while T3 showed a mean value of $0.20 \%$. In sensory evaluation, between 7 and 28 days, scores varied from -like moderately- to -like very much-, with mean values of 8.06 - 7.92; 7.36 - 7.8; 7.1 - 7.06 and 7.6 - 7.5, for $\mathrm{T} 1, \mathrm{~T} 2, \mathrm{~T} 3$ and $\mathrm{T} 4$, respectively. These results demonstrate that the addition of inulin does not affect the viability of the probiotic in ice cream developed. However, the developed ice cream presented satisfactory populations of La-5, remaining above the minimum required by Brazilian law ( $6 \log \mathrm{CFU} / \mathrm{g}$ ), and was well accepted by the consumers. Therefore, ice cream can be considered an excellent food matrix for functional ingredient delivery.

Palavras-Chave: Probiotic, Prebiotic, Functional food, Lactobacillus acidophilus

Agência de Fomento: CAPES; CNPq; UNOPAR. 